\title{
Evapotranspiration and water-use efficiency of irrigated colored cotton cultivar in semiarid regions
}

\author{
Pedro V. de Azevedo ${ }^{1 *}$, José R. C. Bezerra ${ }^{2}$, Vicente de P. R. da Silva ${ }^{1}$ \\ ${ }^{1}$ Federal University of Campina Grande, Campina Grande, Brazil; * Corresponding Author: pvieira@dca.ufcg.edu.br \\ ${ }^{2}$ Brazilian Company for Agriculture and Animal Research (Embrapa Algodão), Campina Grande, Brazil
}

Received 5 June 2012; revised 16 July 2012; accepted 2 August 2012

\section{ABSTRACT}

Irrigation studies provide a framework for evaluating agricultural production and the water resource management in locations where water is scarce. Field experiments were conducted at Barbalha-CE (Northwestern Brazil) during 2004 and 2005 cropping seasons to investigate the effects of different irrigation water depths on the water-use efficiency and yield of the BRS 200brown cotton cultivar (Gossypium hirsutum L.). Three irrigation treatments were applied: $T_{1}=$ $80 \% ; T_{2}=100 \%$ and $T_{3}=120 \%$ of the potential evapotranspiration $\left(\mathrm{ET}_{\mathrm{p}}\right)$. The Bowen ratio-energy balance was used to obtain crop evapotrnaspiration $\left(E T_{c}\right)$ while daily reference evapotranspiration $\left(\mathrm{ET}_{\mathrm{o}}\right.$ ) was obtained by the PenmanMonteith approach. Irrigation water was applied by a sprinkler system during both cropping seasons. The daily evapotranspiration ranged from $2.59 \mathrm{~mm} \cdot \mathrm{day}^{-1}$ at the emergence to $5.89 \mathrm{~mm} \cdot$ day $^{-1}$ at first square growth stage with an accumulated value of $528.7 \mathrm{~mm}$ as a mean of the two cropping seasons. The average crop coefficient across both years (2004-2005) was 0.90 , with minimum and maximum values of 0.46 and 1.17 at emergency and first flower growth stages, respectively. The results also showed that the increase in irrigation from $80 \%$ to $120 \%$ of $\mathrm{ET}_{\mathrm{p}}$ resulted in a significant increase in the seedcotton yield (from 2476.0 to $3289.5 \mathrm{~kg} \cdot \mathrm{ha}^{-1}$ ), while lint percentage and water-use efficiency (WUE) were slightly reduced from $35.7 \%$ to $35.6 \%$ and from 0.60 to $0.53 \mathrm{~kg} \cdot \mathrm{m}^{-3}$, respectively. These results suggests that the cotton crop (cultivar BRS-200 brown) reaches higher water-use efficiency when irrigated with $80 \%$ of the crop evapotranspiration obtained as a function of the reference evapotranspiration and the crop coefficient proposed by FAO. However, the maximum seedcotton yield is obtained when irrigated with
$120 \%$ of that crop evapotranspiration.

Keywords: Bowen Ratio; Crop Evapotranspiration; Irrigation Treatments; Seed-Cotton Yield

\section{INTRODUCTION}

Agriculture is largely responsible for the increase in world water consumption due to the worldwide increases in agricultural irrigation areas that were needed to maintain a satisfactory level of food production for the human population. In semiarid regions, determining the timing of irrigation and quantifying the amount of complementary irrigation that is required are important due to the irregularity of rainfall events. Increasing crop water-use efficiency (WUE) to increase agricultural production without increasing the volume of water that is used for irrigation has become more challenging for these regions. Some studies have shown that an increase in irrigation water volume does not necessarily result in crop yield increases [1,2], but WUE values generally decrease with increasing irrigation water levels for all productivity parameters [3]. Many studies have demonstrated an increase in food production by increasing WUE. In other studies, a higher WUE resulted in either the same food production from fewer water resources or higher production from the same water resources [4]. There is an urgent need in the agricultural sector to use dwindling water resources efficiently to enhance WUE at the farm level [5]. These authors have observed that the water-use efficiency could be enhanced by reducing evapotranspiration through irrigation deficit and by identifying the crop growth stage that is most sensitive to water stress.

Previous studies have reported that the WUE for cotton is a key element for long-term, strategic water resource planning [6-8]. Other researchers have investigated furrow and drip irrigation scheduling as well as computer models for evaluating alternative irrigation strategies for cotton production in arid, semiarid and humid environments [9]. A cotton field experiment was performed to compare drip to furrow (conventional) irri- 
gation for a deep silt loam soil in Uzbekistan over three consecutive years [10]. They found that WUE values were always significantly higher for drip than for furrow irrigation. All of these studies have greatly contributed to an increase in crop productivity by using less water and improving new drought-tolerant cotton varieties. Also, some studies have been conducted for increasing cotton crop yield with less water consumption [11-14]. By comparing irrigation systems, a single-row cotton crop was more water efficient when irrigated by furrow line while a double-row crop was more water efficient when a dripping irrigation system was used [5]. Also, [15] observed that water-use efficiency increased with increasing irrigation frequency.

Cotton crops have been widely cultivated in semiarid and other wet regions of the world using rain-fed systems. However, cotton growth under full or supplementary irrigation may be an alternative method for increasing crop productivity. The loss of productivity due to the lack of rainfall events has threatened farming systems. Also, cotton crops are sensitive to low temperatures and excess soil water when the plants are emerging from the soil. In many rainy years the rain-fed cotton crop has resulted in yield reductions and quality deterioration [16]. These challenges do not completely prevent cotton crop growth in the semiarid regions because air temperature is always approximately $20^{\circ} \mathrm{C}$ and the annual mean rainfall is below $800 \mathrm{~mm}$ [17]. Therefore, as an alternative agricultural practice for improving the rain-fed system, the cotton crops have been grown in a polyculture system with maize (Zea mays) and beans (Phaseolus vulgaris). In other regions of Brazil, cotton is typically grown in rotations with at least three other crops, such as soybeans (Glycine $\max$ L.), millet (Pennisetum glaucum L.) and soybean-millet-cotton, which has resulted in better weed control than rotations with fewer crops [18]. [19] has mentioned the effects of growing cereal and leguminous crops in rotation with dry land cotton on the physical and chemical properties of grey vertisol soil. Sowing other crops in rotation with cotton has been a successful strategy for reversing yield decline and maintaining soil quality [20]. These alternative agricultural management practices have been proposed to reduce soil degradation in cotton cropping systems.

Cotton was one of the most important crops in Brazil, particularly in the semiarid region of northeastern Brazil, before the appearance of the boll weevil (Anthonomus grandis Boheman). This cotton pest was introduced to Brazil in 1983, and it causes serious damage to crops, including the removal of flower buds, destruction of bolls and reduced lint production. In 2000, the Brazilian Company for Agriculture and Animal Research (EMBRAPA) released a genetically modified cotton crop (BRS 200-brown) cultivar that was more resistant to the boll weevil pest. However, there is little information on how this cultivar responds to changes in soil water content, which would be useful for irrigation scheduling strategies. Additionally, little is known about the economic viability of this new cultivar which has strong vegetative development when grown in soil with high water content. Therefore, it is necessary to carry out more studies for identifying the best irrigation water depth to obtain higher cotton yields as well as to evaluate new cultivation techniques for reducing the cost and increasing the yields of this cultivar. Therefore, the purpose of this study was to evaluate the effect of the water treatment on the evapotranspiration and water use-efficiency of the BRS 200-brown cotton cultivar grown in semiarid regions under sprinkler irrigation.

\section{MATERIALS AND METHODS}

\subsection{Experimental Site and Weather Data}

Field experiments were conducted at the Experimental Station of the Brazilian Company for Agriculture and Animal Research (Embrapa Algodão) in Barbalha, CE, Brazil $\left(7^{\circ} 19^{\prime} \mathrm{S} ; 39^{\circ} 18^{\prime} \mathrm{W}\right.$ and $415.7 \mathrm{~m}$ elevation above mean sea level). The local climate was a tropical wet climate with tropical savanna vegetation and the soil type was Lixisols (FAO soil taxonomy). The air temperature ranged from $19^{\circ} \mathrm{C}$ (rainy season) to $34^{\circ} \mathrm{C}$ (dry season), and the annual mean rainfall was $1000 \mathrm{~mm}$ [17]. The weather data (Air temperature, Class A pan evaporation, relative humidity and rainfall) were collected from a weather station adjacent to the experimental field during the two cropping seasons (Table 1).

The total rainfall plus irrigation (Figure 1) and the temporal course of solar radiation and wind speed (Figure 2) during the cropping seasons of 2004 (July to November) and 2005 (September to December) were also determined.

\subsection{Crop and Water Management}

Crop phenology was divided into four growth stages (Table 2) based on field observations from both cropping seasons as a function of days after sowing (DAS). Cotton crop (Gossypium hirsutum L.), cultivar BRS 200-brown, was cultivated using different soil water contents during the 2004 (July 29 to November 10) and 2005 (September 02 to December 15) cropping seasons (Table 3). Three irrigation treatments were applied: $\mathrm{T}_{1}: 80 \% \mathrm{ET}_{\mathrm{p}} ; \mathrm{T}_{2}$ : $100 \% \mathrm{ET}_{\mathrm{p}}$ and $\mathrm{T}_{3}: 120 \% \mathrm{ET}_{\mathrm{p}}$ where $\mathrm{ET}_{\mathrm{p}}$ is the potential evapotranspiration obtained as the product of the reference evapotranspiration- $\mathrm{ET}_{0}$ [21] by the crop coefficient $\left(\mathrm{K}_{\mathrm{c}}\right)$ suggested by FAO [22].

Irrigation water was applied with a sprinkler system during both cropping seasons. The sprinklers (Agropolo) 
Table 1. Long-term monthly (1911-2004) means and 2004 (July-Dec) and 2005 (Sept-Dec) growing seasons air temperature (maximum, minimum and average), pan evaporation, relative humidity and rainfall at Barbalha, CE, Brazil.

\begin{tabular}{|c|c|c|c|c|c|c|c|}
\hline \multirow{2}{*}{ years } & \multirow{2}{*}{ months } & \multicolumn{3}{|c|}{ air temperature $\left({ }^{\circ} \mathrm{C}\right)$} & \multirow{2}{*}{ pan evaporation (mm) } & \multirow{2}{*}{ relative humidity (\%) } & \multirow{2}{*}{ rainfall $(\mathrm{mm})$} \\
\hline & & $\mathrm{T}_{\max }$ & $\mathrm{T}_{\min }$ & $\mathrm{T}_{\text {average }}$ & & & \\
\hline \multirow[t]{6}{*}{ 1911-2004 } & Jul & 29.9 & 19.1 & 23.8 & 224.8 & 61.0 & 11.6 \\
\hline & Ago & 31.7 & 18.1 & 24.9 & 268.7 & 53.0 & 7.4 \\
\hline & Sept & 33.3 & 20.1 & 26.2 & 292.8 & 49.0 & 12.4 \\
\hline & Oct & 34.1 & 21.1 & 26.7 & 262.9 & 51.0 & 36.3 \\
\hline & Nov & 33.9 & 21.8 & 26.8 & 223.7 & 53.0 & 35.5 \\
\hline & Dec & 33.1 & 21.7 & 26.3 & 216.1 & 55.0 & 98.2 \\
\hline \multicolumn{2}{|c|}{ mean } & 32.7 & 20.3 & 25.8 & 248.1 & 53.7 & 33.6 \\
\hline \multirow[t]{6}{*}{2004} & Jul & 32.3 & 15.6 & 24.0 & - & 68.9 & 2.6 \\
\hline & Ago & 35.8 & 17.5 & 25.2 & 388.6 & 61.0 & 6.9 \\
\hline & Sept & 37.2 & 18.0 & 26.7 & 284.3 & 52.7 & 0.0 \\
\hline & Oct & 37.1 & 18.5 & 28.0 & 403.6 & 54.2 & 0.0 \\
\hline & Nov & 38.1 & 19.2 & 27.8 & 274.6 & 57.6 & 32.6 \\
\hline & & 36.1 & 17.8 & 26.3 & 337.8 & 58.9 & 8.4 \\
\hline \multirow[t]{5}{*}{2005} & Sept & 36.3 & 17.2 & 26.7 & 356.4 & 50.2 & 0.0 \\
\hline & Oct & 37.4 & 20.2 & 28.4 & 372.9 & 45.8 & 0.4 \\
\hline & Nov & 37.7 & 20.4 & 28.5 & 306.5 & 49.1 & 0.0 \\
\hline & Dec & 35.9 & 20.3 & 26.9 & 437.4 & 65.7 & 194.5 \\
\hline & mean & 36.8 & 19.6 & 27.6 & 368.3 & 52.7 & 48.7 \\
\hline
\end{tabular}

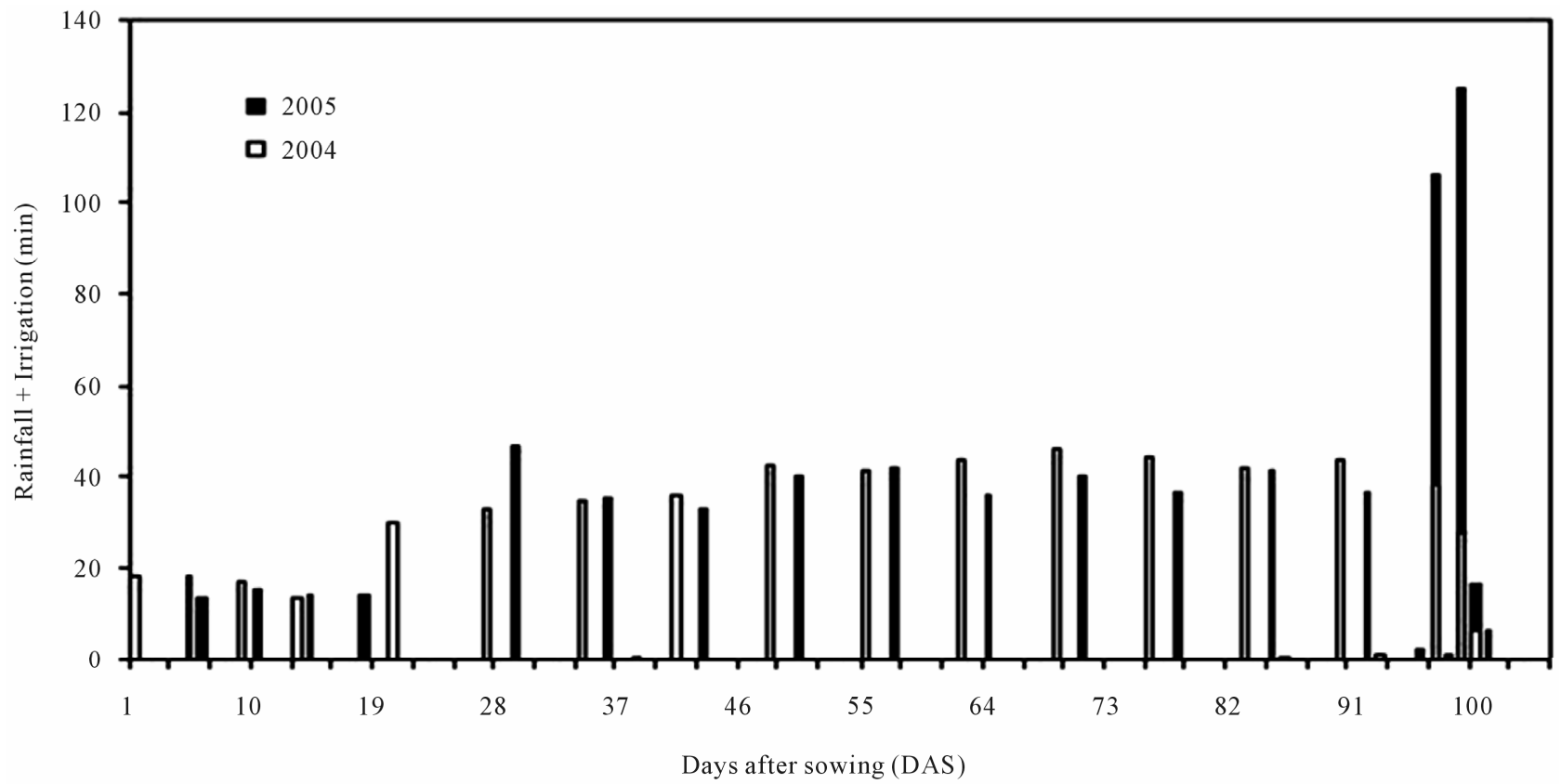

Figure 1. Temporal course of rainfall plus irrigation during the 2004 (July 29 to November 10) and 2005 (September 02 to December 15) cropping seasons at Barbalha, CE, Brazil. 


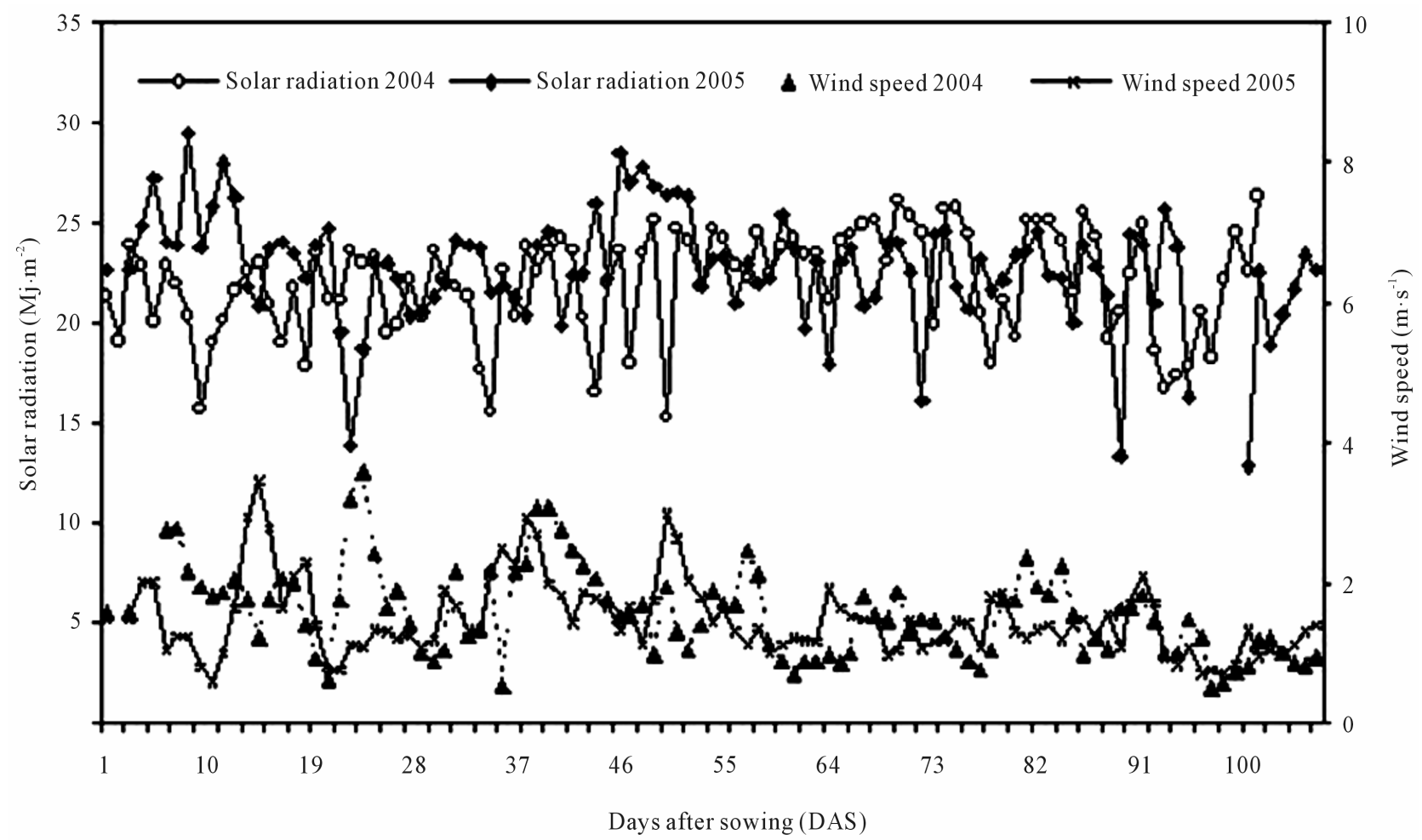

Figure 2. Pattern of solar radiation and wind speed over the cotton crop (cultivar BRS 200 Brown) during the 2004 (from September 02 to December 15) and 2005 (from July 29 to November 10) cropping seasons at Barbalha, CE, Brazil.

Table 2. Growth stages of the cotton crop (cultivar BRS-200 brown) during the 2004 (from September 02 to December 15) and 2005 (from July 29 to November 10) cropping seasons at Barbalha, CE, Brazil.

\begin{tabular}{|c|c|c|c|c|}
\hline \multirow{2}{*}{ Growth Stage } & \multicolumn{2}{|c|}{ Dates } & \multirow{2}{*}{ Days after sowing (DAS) } & \multirow{2}{*}{ Time periods (days) } \\
\hline & Year 2004 & Year 2005 & & \\
\hline Emergency & Jul, 29 to Aug, 11 & Sept, 02 to Sept, 16 & $01-15$ & 15 \\
\hline First Square & Aug, 12 to Sep, 20 & Sept, 17 to Oct, 25 & $16-54$ & 39 \\
\hline First Flower & Sept, 21 to Oct, 20 & Oct, 26 to Nov, 25 & $55-85$ & 31 \\
\hline Open Boll & Oct, 21 to Nov, 10 & Nov, 26 to Dec, 15 & $86-105$ & 20 \\
\hline Total & & & & 105 \\
\hline
\end{tabular}

Table 3. Components of seed-cotton (cultivar BRA-200 Brown) yield and water-use efficiency (WUE) as influenced by irrigation treatments (averaged for the 2004 and 2005 cropping seasons) at Barbalha, CE, Brazil.

\begin{tabular}{cccc}
\hline Irrigation treatment & Seed-cotton yield $\left(\mathrm{kg} \cdot \mathrm{ha}^{-1}\right)$ & Lint percentage $(\%)$ & WUE $\left(\mathrm{kg} \cdot \mathrm{m}^{-3}\right)$ \\
\hline $\mathrm{T}_{1}=80 \%\left(\mathrm{ET}_{\mathrm{p}}\right)=411.6 \mathrm{~mm}$ & $2476.0^{\mathrm{b}}$ & $35.7^{\mathrm{a}}$ & 0.60 \\
$\mathrm{~T}_{2}=100 \%\left(\mathrm{ET}_{\mathrm{p}}\right)=514.5 \mathrm{~mm}$ & $2848.8^{\mathrm{ab}}$ & $35.7^{\mathrm{a}}$ & 0.55 \\
$\mathrm{~T}_{3}=120 \%\left(\mathrm{ET}_{\mathrm{p}}\right)=617.4 \mathrm{~mm}$ & $3289.5^{\mathrm{a}}$ & $35.6^{\mathrm{a}}$ & 0.53 \\
\hline
\end{tabular}

Means followed by the same letter are not significantly different by the Duncan test at the $5 \%$ significance level.

had a mouthpiece emitter discharge of $3.2 \times 5.4 \mathrm{~mm}$ spaced over an $18 \times 12 \mathrm{~m}$ area with an operating pressure of $2.5 \mathrm{~atm}$. The crop was planted in double rows in a main plot of 1006 ha with $1.0 \times 0.40 \mathrm{~m}$ spacing between each row and a population density of 10 plants $\cdot \mathrm{m}^{-2}$. The irrigation treatments were laid out in a split plot arrangement in a randomized block design with four replications of three different water treatments. The crop yield 
was obtained by hand harvesting the central rows of each sub-plot two times during the cropping seasons: the first harvest occurred at $60 \%$ boll formation and the second harvest occurred at $100 \%$ boll formation. The total amount of fertilizer applied to all the plots before cotton sowing was $30 \mathrm{~kg} \cdot \mathrm{N} \cdot \mathrm{ha}^{-1}, 60 \mathrm{~kg} \cdot \mathrm{P}_{2} \mathrm{O}_{5} \cdot \mathrm{ha}^{-1}$ and 10 $\mathrm{kg} \cdot \mathrm{K}_{2} \mathrm{O} \cdot \mathrm{ha}^{-1}$.

The experimental plot was fully irrigated until the available soil content reached $100 \%$ before crop sowing. Four days after sowing (DAS), a short period of irrigation was applied to ensure good seed germination. After the crop was fully established, the irrigation was applied weekly as a function of the water consumption established by crop evapotranspiration.

\subsection{Environmental Measurements}

Measurements of global and reflected solar radiation, net radiation, dry and wet bulb air temperature (at 0.30 and $1.5 \mathrm{~m}$ above the crop canopy), wind speed (at 0.30 and $1.5 \mathrm{~m}$ above the crop canopy), and soil heat flux (at $0.02 \mathrm{~m}$ below the soil surface) were obtained during the experimental periods. The sensors were connected to a data acquisition system (Data logger CR 10X, Campbell Scientific Inc.) programmed for collecting data every $5 \mathrm{~s}$ and storage averages every $20 \mathrm{~min}$. Wet and dry bulb temperatures were measured by a ventilated

psychrometer held about $0.5 \mathrm{~m}$ above the crop canopy. The micrometeorology tower was installed at the experimental plot with a fetch of $80 \mathrm{~m}$ in the main wind direction. All of these sensors were calibrated prior to the experimental periods.

\subsection{Crop and Reference Evapotranspiration}

Daily reference evapotranspiration $\left(\mathrm{ET}_{\mathrm{o}}\right)$ was obtained by the Penman-Monteith method [21] by using climate data from a weather station located $400 \mathrm{~m}$ from the experimental site. Further details regarding this method can be found in [1].

The above canopy latent heat flux was obtained by the energy balance method by neglecting the advection effects, the energy stored in the canopy and the photosynthetic energy flux. Thus, assuming equality between the turbulent diffusion coefficients of sensible $\left(K_{h}\right)$ and latent $\left(K_{w}\right)$ heat fluxes and $(\partial T / \partial z) /\left(\partial e_{a} / \partial z\right) \approx \Delta T / \Delta e_{a}$ the latent heat flux $\left(\lambda E\right.$, in $\left.\mathrm{W} \cdot \mathrm{m}^{-2}\right)$, based on the Bowen ratio $\left(\beta=H / \lambda E \cong \chi\left(\Delta T / \Delta e_{a}\right)\right.$, was obtained as:

$$
\lambda E=-\left(\frac{R_{n}-G}{1+\gamma\left(\Delta T / \Delta e_{a}\right)}\right)
$$

where $\left.\lambda=2.501 \mathrm{MJ} \cdot \mathrm{kg}^{-1}\right)$ is the latent heat of vaporization, $R_{n}\left(\mathrm{~W} \cdot \mathrm{m}^{-2}\right)$ the net radiation, $G\left(\mathrm{~W} \cdot \mathrm{m}^{-2}\right)$ the soil heat flux, $\gamma\left(\mathrm{kPa} \cdot{ }^{\circ} \mathrm{C}^{-1}\right)$ the psychrometric constant and $\Delta T$ $\left({ }^{\circ} \mathrm{C}\right)$ and $\Delta e_{a}(\mathrm{kPa})$ are the temperature and vapor pressure differences between two measurement levels at 0.5 and $1.5 \mathrm{~m}$ heights above cotton canopy. The components of the energy balance were obtained for the daytime period (i.e., $R_{n}>0$ ) and were considered positive when upward and negative when downward crop canopy [3,23-25]. Also, the set of criteria suggested by [26] was adopted for selecting between reliable and unreliable values of $\beta$ for daytime periods with $R_{n}>0$. The crop evapotranspiration $\left(\mathrm{ET}_{\mathrm{c}}\right)$ was then obtained in $\mathrm{mm} \cdot$ day $^{-1}$ by dividing $\lambda E$ by $\lambda$, and integrating the mean values collected by the data acquisition system for day-time period with $R_{n}-G>0$ [23].

The water use-efficiency (WUE) was calculated as the ratio of seed-cotton yield to total water use and was expressed as $\mathrm{kg} \cdot \mathrm{ha}^{-1} \cdot \mathrm{mm}^{-1}$ [27].

\subsection{Statistical Analysis}

An analysis of variance (ANOVA) was conducted to evaluate the effects of the irrigation water depths on seed cotton yield by using ASSISTAT software [28]. The significant difference of the means was analyzed by Duncan's multiple range tests with significance levels of $1 \%$ and $5 \%$.

\section{RESULTS AND DISCUSSION}

\subsection{Crop Evapotranspiration}

During the 2004 growing season, the daily crop evapotranspiration $\left(\mathrm{ET}_{\mathrm{c}}\right)$ varied from 3.2 to $7.1 \mathrm{~mm} \cdot$ day $^{-1}$ with an average and standard deviation of $5.4 \pm 0.9 \mathrm{~mm} \cdot \mathrm{day}^{-1}$. In 2005 , the $\mathrm{ET}_{\mathrm{c}}$ values varied from 2.9 to $5.0 \mathrm{~mm} \cdot \mathrm{day}^{-1}$ with an average and standard deviation of $5.0 \pm 0.87$ $\mathrm{mm} \cdot$ day $^{-1}$. On the other hand, the accumulative values of $\mathrm{ET}_{\mathrm{c}}$ were 545.0 and $512.4 \mathrm{~mm}$ for the growing seasons of 2004 and 2005, respectively with an average of 528.7 $\mathrm{mm}$ (Table 4). Therefore, the $\mathrm{ET}_{\mathrm{c}}$ was $6.3 \%$ higher in 2004 as compared to 2005. These differences in evapotranspiration $\left(\mathrm{ET}_{\mathrm{c}}\right)$ between the experimental years could be attributed to higher values in solar radiation and wind speed during the 2004 year, which likely produced a higher evaporative demand (Figure 2).

The lower water input (irrigation plus rainfall) in the 2004 growing season $(580.1 \mathrm{~mm})$ compared to that of $2005(632.8 \mathrm{~mm})$ did not significantly affected cotton crop evapotranspiration or the crop coefficient (Figure 3). According to [29] the crop evapotranspiration is higher for days after irrigation or after rainfall events when there is higher level of energy available to the evapotranspiration process. The results of this study did not always agreed with these findings once the plants reached the open boll growth stage (at the end of the cotton cropping cycle) during two consecutive days of 

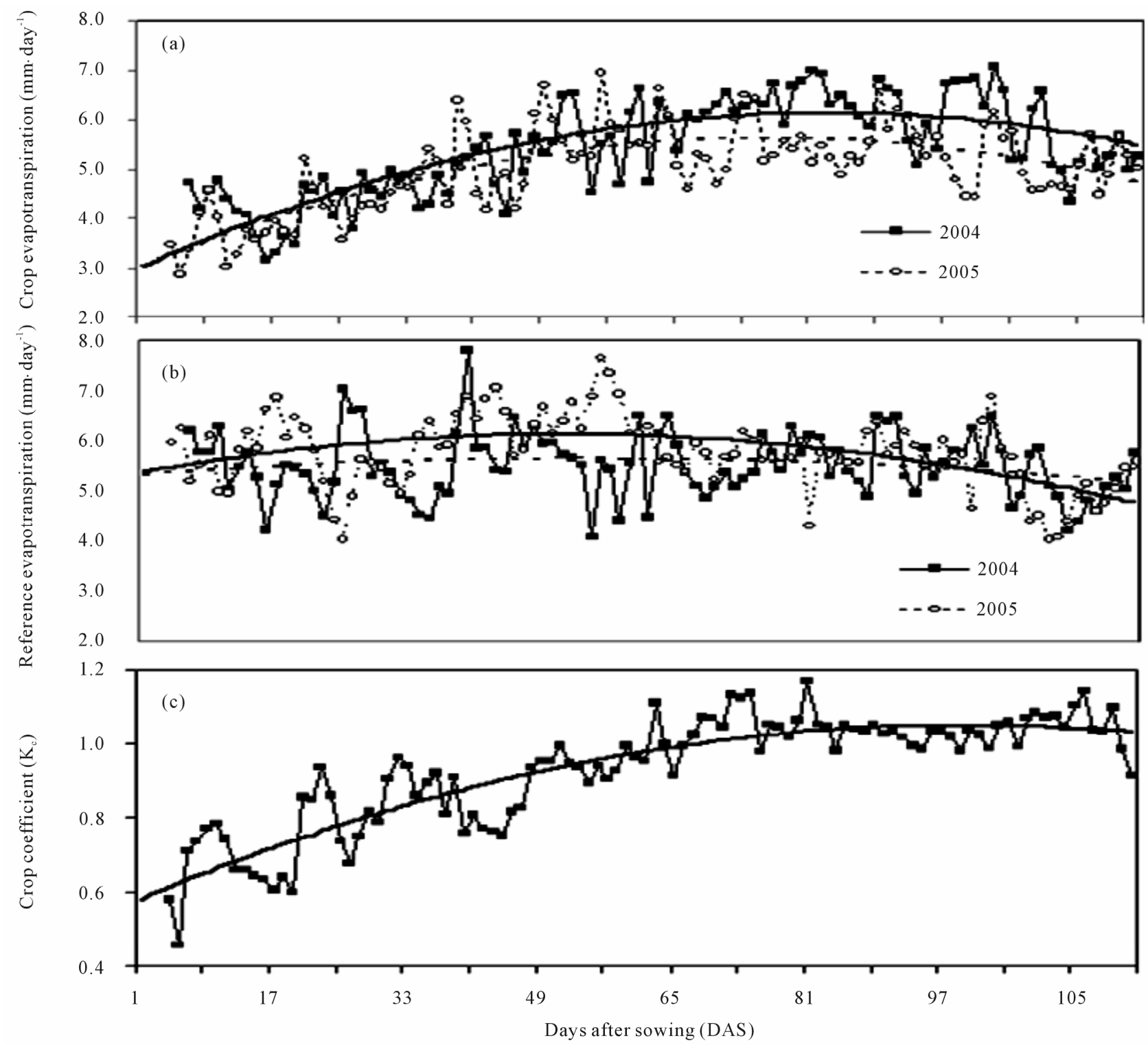

Figure 3. Cotton crop evapotranspiration (a), reference evapotranspiration (b) and crop coefficient (c) for the 2004 (from September 02 to December 15) and 2005 (from July 29 to November 10) cropping seasons at Barbalha, CE, Brazil. The crop coefficient is an average for the 2004 and 2005 cropping seasons.

Table 4. Mean and accumulated daily cotton crop evapotranspiration $\left(\mathrm{ET}_{\mathrm{c}}\right)$ for each growth stages for the cropping seasons of 2004 (from September 02 to December 15) and 2005 (from July 29 to November 10) at Barbalha, CE, Brazil.

\begin{tabular}{ccccc}
\hline \multirow{2}{*}{ Growth stage } & \multicolumn{3}{c}{ ET $_{\mathrm{c}}(\mathrm{mm})$} \\
\cline { 2 - 5 } & Mean $\left(\mathrm{mm} \cdot\right.$ day $\left.^{-1}\right)$ & 2004 & 2005 & Mean $(2004-2005)$ \\
\hline Emergency (15 days) & 2.59 & 37.7 & 39.9 & 38.8 \\
First Square (39 days) & 4.95 & 193.1 & 193.4 & 193.3 \\
First Flower (31 days) & 5.89 & 192.1 & 172.4 & 182.3 \\
Open Boll (20 days) & 5.72 & 122.1 & 106.7 & $\mathbf{5 1 4 . 4}$ \\
Total & - & $\mathbf{5 4 5 . 0}$ & $\mathbf{5 1 2 . 4}$ & - \\
Average & $\mathbf{4 . 7 8}$ & - & $\mathbf{5 2 8 . 7}$
\end{tabular}


intense cloudiness and rainfall that reduced solar radiation and wind speed (Figures 1 and 2). These climatic conditions produced low values for crop evapotranspiration even when the soil moisture content was high.

Also, the minimum daily evapotranspiration (2.59 $\mathrm{mm} \cdot$ day $^{-1}$ ) occurred during the emergence growth stage while the maximum value $\left(5.89 \mathrm{~mm} \cdot \mathrm{day}^{-1}\right)$ occurred at first square stage as a mean of the two cropping seasons (Table 4). Then, both crop evapotranspiration and crop coefficient increased as the plants grew to the open boll stage (Figure 3) indicating that the crop coefficient was dependent on crop evapotranspiration throughout the two cropping seasons. The cotton open boll growth stage has been shown to be sensitive to soil water deficit [5]. During this growth stage, the water input in 2004 and 2005 were 176.4 and $155.2 \mathrm{~mm}$, respectively. Consequently, there was not any water deficit for the cotton crop for either experimental year. As the evapotranspiration decreased during this growth stage, the water input was primarily responsible for the increase in crop evapotranspiration and crop coefficient. This result agrees with the findings of [30], who observed that irrigation was largely responsible for the boll number of cotton and about $70 \%$ - $75 \%$ of seasonal evapotranspiration in all irrigation treatments occurred roughly during the 85 - 92 day period between sowing the seeds to full bloom.

\subsection{Crop Coefficient}

The average of the crop coefficient $\left(\mathrm{K}_{\mathrm{c}}\right)$ values across both years (2004-2005) was 0.90, with maximum and minimum values of 1.17 and 0.46 at first flower and emergency growth stages, respectively (Figure 3 ). Similar results were found in a study by [30] to determine water use and the lint yield response of drip irrigated cotton in a semiarid region. They obtained average $\mathrm{K}_{\mathrm{c}}$ values ranging from 0.58 at the initial growth stage to 1.10 at the mid growth stage. The accumulated ET was $642 \mathrm{~mm}$ for a total growing season of 134 days. Similarly, [31] obtained a $\mathrm{K}_{\mathrm{c}}$ of 0.53 at emergence, 1.15 at heading and 0.40 at hard dough for cotton. The $\mathrm{K}_{\mathrm{c}}$ values obtained in this study were also similar to those reported in $\mathrm{FAO} / 56$ [21], but the values were slightly higher at the open boll growth stage. The disagreements between $\mathrm{K}_{\mathrm{c}}$ values from these studies could be attributed to differences in climate and cotton variety.

\subsection{Seed-Cotton Yield and Water-Use Efficiency}

The effects of irrigation treatments on the components of seed-cotton yield and water-use efficiency are shown in Table 3. An analysis of variance showed that only seed-cotton yield was affected by irrigation water depth. The increases in irrigation from $T_{1}$ to $T_{3}$ treatment re- sulted in a significant increase in the seed-cotton yield (from 2476.0 to $3289.5 \mathrm{~kg} \cdot \mathrm{ha}^{-1}$ ), while lint percentage and WUE values were slightly reduced from $35.7 \%$ to $35.6 \%$ and from 0.60 to $0.53 \mathrm{~kg} \cdot \mathrm{m}^{-3}$, respectively. These lint percentage results were consistent with the values obtained by Karam et al. (2006), who reported a reduction in the cotton lint yield values as the irrigation amounts increased. Higher cotton yield values were obtained from the highest irrigation treatment $\left(\mathrm{T}_{3}\right)$, but the values were slightly lower than those reported in other studies $[8,9]$ and much higher than those found by [2] and [32].

Although there was a slight decrease according to increasing irrigation depth, no significant differences were detected in water-use efficiency (Table 3). These results may be associated with the physiological crop response to greater soil water availability for all of irrigation treatments. The soil water availability also affected the plants physiological processes, primarily the crop growth and vegetative development [22] as well as photosynthesis and leaf expansion [33]. Both seed-cotton yield and water-use efficiency (WUE) decreased linearly with increasing irrigation water treatment. Also, the increases on irrigation treatment from $T_{1}$ to $T_{3}$ resulted in a $24.7 \%$ increase in seed-cotton yield and a $11.7 \%$ decrease in WUE values (Table 3), which are similar to the values reported in the literature [8]. These results means that the cotton crop (cultivar BRS-200 brown) reaches higher water-use efficiency when irrigated with $80 \%$ of the crop evapotrnaspiration obtained as a function of the reference evapotranspiration and the crop coefficient proposed by FAO. However, the maximum seed-cotton yield is obtained when irrigated with $120 \%$ of that crop evapotranspiration.

The values of water-use efficiency and seed-cotton yield from this study are reported as the average over two years (2004-2005) since the results were similar for both experimental years. The seed-cotton yield range was similar to those reported in the current literature [8,9,34]. However, the yield variation from 2476 to $3289 \mathrm{~kg} \cdot \mathrm{ha}^{-1}$ for the colored cotton cultivar does not offset the high cost of sowing the cultivar (Table 5). [2] has reported that the economic costs and values used for the full irrigation rate did not improve net return over the $66 \%$ rate during the experimental years. Also, the results indicated that the WUE values ranging from 0.53 to $0.60 \mathrm{~kg} \cdot \mathrm{m}^{-3}$ were well within of range reported by these studies and close to the FAO 33 range $\left(0.4-0.6 \mathrm{~kg} \cdot \mathrm{m}^{3}\right)$ reported by [22].

\section{CONCLUSIONS}

Field experiments were carried out during two consecutive years with the primary objective of evaluating the evapotranspiration, seed yield and water-use efficiency of the cotton crop (cultivar BRS-200 brown) 
Table 5. Summary of range in water use efficiency (WUE) and seed-cotton yield values in comparison with other researches values.

\begin{tabular}{|c|c|c|c|c|}
\hline Literature source & Irrigation system & WUE $\left(\mathrm{kg} \cdot \mathrm{m}^{-3}\right)$ & Seed-cotton yield $\left(\mathrm{kg} \cdot \mathrm{ha}^{-1}\right)$ & Cost of sowing (US\$ $\cdot \mathrm{ha}^{-1}$ ) \\
\hline This study & Sprinkler & $0.53-0.60$ & $2476-3289$ & 1489.18 \\
\hline Dagdelen et al. (2009) & Drip & $0.77-0.96$ & $2550-5760$ & - \\
\hline Pereira et al. (2009) & - & - & $2723-3722$ & - \\
\hline Nuti et al. (2009) & Furrow & - & $1017-1476^{\mathrm{a}}$ & - \\
\hline Martin \& Hanks (2009) & Furrow & - & $1112-1325^{\mathrm{a}, \mathrm{b}}$ & - \\
\hline Nazirbay et al. (2007) & Drip + furrow & $0.50-0.88$ & $3180-4030$ & - \\
\hline Du et al. (2006) & Furrow & $0.58-1.99^{\mathrm{d}}$ & $1611-2564$ & - \\
\hline Aujla et al. (2005) & Drip & $0.17-0.23^{\mathrm{e}}$ & $931-2144$ & - \\
\hline Cetin \& Bilgel (2002) & Drip/furrow/sprinkler & $0.24-0.49^{\mathrm{d}}$ & $850-4900$ & - \\
\hline
\end{tabular}

${ }^{\mathrm{a}}$ Seed-cotton yield; ${ }^{\mathrm{B}}$ converted values from $\mathrm{lbs} / \mathrm{acre}$ to $\mathrm{kg} \cdot \mathrm{ha}^{-1} ;{ }^{\mathrm{c}}$ Converted values from $\$ /$ acre to US\$ $\cdot \mathrm{ha}^{-1}$; ${ }^{\mathrm{d}} \mathrm{Converted} \mathrm{values} \mathrm{from} \mathrm{kg} \cdot \mathrm{ha}^{-1} \cdot \mathrm{mm}^{-1}$ to $\mathrm{kg} \cdot \mathrm{m}^{-3}$; ${ }^{\mathrm{e}}$ Converted values from $\mathrm{kg} / \mathrm{ha} \mathrm{cm}$ to $\mathrm{kg} \cdot \mathrm{m}^{-3}$.

grown under sprinkler irrigation.

The daily evapotranspiration ranged from $2.59 \mathrm{~mm} \cdot$ day $^{-1}$ at the emergence to $5.89 \mathrm{~mm} \cdot$ day $^{-1}$ at first square growth stage with an accumulated value of $528.7 \mathrm{~mm}$. For the growing cycle the average daily value of the crop coefficient was 0.90 , with minimum and maximum values of 0.46 and 1.17 at emergency and first flower growth stages, respectively.

The results also showed that the increase in irrigation from $80 \%$ to $120 \%$ of $\mathrm{ET}_{\mathrm{p}}$ resulted in a significant increases in the seed-cotton yield (from 2476.0 to 3289.5 $\mathrm{kg} \cdot \mathrm{ha}^{-1}$ ), while lint percentage and water-use efficiency (WUE) were slightly reduced from $35.7 \%$ to $35.6 \%$ and from 0.60 to $0.53 \mathrm{~kg} \cdot \mathrm{m}^{-3}$, respectively. These results suggests that the cotton crop (cultivar BRS-200 brown) reaches higher water-use efficiency when irrigated with $80 \%$ of the crop evapotranspiration obtained as a function of the reference evapotranspiration and the crop coefficient proposed by FAO. However, the maximum seed-cotton yield is obtained when irrigated with $120 \%$ of that crop evapotranspiration.

\section{ACKNOWLEDGEMENTS}

This study was partially supported by the National Council of Scientific and Technological Research- $\mathrm{CNPq} /$ Brazil. The authors would like to thank the National Center for Cotton Research - CNPA and the Brazilian Company for Agriculture and Animal Research-EMBRAPA, for allowing us to use their facilities, including laboratories, library and field experimental stations.

\section{REFERENCES}

[1] Silva, V.P.R., Campos, J.H.B.C. and Azevedo, P.V. (2009) Water-use efficiency and evapotranspiration of mango orchard grown in northeastern region of Brazil. Scientific Horticulture, 120, 67-472.

[2] Nuti, R.C., Lamb, M.C., Sorensen, R.B. and Truman, C.C.
(2009) Agronomic and economic response to furrow diking tillage in irrigated and non-irrigated cotton (Gossypium hirsutum L.). Agriculture Water Management, 96, 1078-1084. doi:10.1016/j.agwat.2009.03.006

[3] Azevedo, P.V., Sousa, I.F., Silva, B.B. and Silva, V.P.R. (2006) Water-use efficiency of dwarf-green coconut ( $\mathrm{Co}$ $\cos$ nucifera L.) orchards in northeast Brazil. Agriculture Water Management, 84, 259-264. doi:10.1016/j.agwat.2006.03.001

[4] Zwart, S.J. and Bastiaanssen, W.G.M. (2004) Review of measured crop water productivity values for irrigated wheat, rice, cotton and maize. Agriculture Water Management, 69, 115-133. doi:10.1016/j.agwat.2004.04.007

[5] Jalota, S.K., Sood, A., Chahal, G.B.S. and Choudhury, B.U. (2006) Crop water productivity of cotton (Gossypium hirsutum L.) and wheat (Triticum aestivum L.) system as influenced by deficit irrigation, soil texture and precipitation. Agriculture Water Management, 84, 137146. doi:10.1016/j.agwat.2006.02.003

[6] Tennakoon, S.B. and Milroy, S.P. (2003) Crop water use and water use efficiency on irrigated cotton farms in Australia. Agriculture Water Management, 61, 179-194. doi:10.1016/S0378-3774(03)00023-4

[7] Dagdelen, N., Y1lmaz, E., Sezgin, F. and Gurbuz, T. (2006) Water-yield relation and water use efficiency of cotton (Gossypium hirsutum L.) and second crop corn (Zea mays L.) in western Turkey. Agriculture Water Management, 82, 63-85. doi:10.1016/j.agwat.2005.05.006

[8] Dagdelen, N., Basal, H., Yılmaz., E., Gurbuz, T. and Akcay, S. (2009) Different drip irrigation regimes affect cotton yield, water use efficiency and fiber quality in western Turkey. Agriculture Water Management, 96, 111-120. doi:10.1016/j.agwat.2008.07.003

[9] Pereira, L.S., Paredes, P., Eholpankulov, E.D., Inchenkova, O.P., Teodoro, P.R. and Horst, M.G. (2009) Irrigation scheduling strategies for cotton to cope with water scarcity in the Fergana Valley, Central Asia. Agriculture Water Management, 96, 723-735. doi:10.1016/j.agwat.2008.10.013

[10] Ibragimov, N., Evett, S.R., Esanbekov, Y., Kamilov, B.S., 
Mirzaev, L. and Lamers, J.P.A. (2007) Water use efficiency of irrigated cotton in Uzbekistan under drip and furrow irrigation. Agriculture Water Management, 90, 112-120. doi:10.1016/j.agwat.2007.01.016

[11] Cetin, O. and Bilgel, L. (2002) Effects of different irrigation methods on shedding and yield of cotton. Agriculture Water Management, 54, 1-15. doi:10.1016/S0378-3774(01)00138-X

[12] Yazar. A., Sezen, S.M. and Sesveren, S. (2002) LEPA and trickle irrigation of cotton in the Southeast Anatolia Project (GAP) area in Turkey. Agriculture Water Management, 54, 189-203. doi:10.1016/S0378-3774(01)00179-2

[13] Aujla, M.S., Thind, H.S. and Buttar, G.S. (2005) Cotton yield and water use efficiency at various levels of water and $\mathrm{N}$ through drip irrigation under two methods of planting. Agriculture Water Management, 71, 167-179. doi:10.1016/j.agwat.2004.06.010

[14] DeTar, W.R. (2008) Yield and growth characteristics for cotton under various irrigation regimes on sandy soil. $\mathrm{Ag}$ riculture Water Management, 95, 69-76. doi:10.1016/j.agwat.2007.08.009

[15] Hunsaker, D.J., Clemmens, A.J. and Fangmeier, D.D. (1998) Cotton response to high frequency surface irrigation. Agriculture Water Management, 37, 55-74. doi:10.1016/S0378-3774(98)00036-5

[16] Stathakos, T.D., Gemtos, T.A., Tsatsarelis, C.A. and Galanopoulou, S. (2006) Evaluation of three cultivation practices for early cotton establishment and improving crop profitability. Soil Tillage Research, 87, 135-145. doi:10.1016/j.still.2005.03.007

[17] Silva, V.P.R. (2004) On climate variability in Northeast of Brazil. Journal of Arid Environment, 58, 575-596. doi:10.1016/j.jaridenv.2003.12.002

[18] Correa, J.C. and Sharma, R.D. (2004) Herbaceous cotton yield in no-till system in rainfed savannah conditions with crop rotation. Pesquisa Agropecuária Brasileira, EMBRAPA, 29, 41-46.

[19] Hulugalle, N.R., Weaver, T.B., Finlay, L.A., Hare, J. and Entwistle, P.C. (2007) Soil properties and crop yields in a dryland vertisol sown with cotton-based crop rotations. Soil Tillage Research, 93, 356-369. doi:10.1016/j.still.2006.05.008

[20] Nkema, J.N., Bruyn, L.A.L., Hulugalle, N.R. and Grant, C.D. (2002) Sowing other crops in rotation with cotton (Gossypium hirsutum L.) has proven to be a successful strategy employed by farmers to reverse yield decline and maintain soil quality. Applied Soil Ecology, 20, 69-74.

[21] Allen, R.G., Pereira, L.S., Raes, D. and Smith, M. (1998) Crop evapotranspiration: Guidelines for computing crop water requirements. United Nations for Food and Agriculture Organization. Irrigation and Drainage, Paper 56, Rome, $300 \mathrm{p}$.

[22] Doorenbos, J. and Kassam, A.H. (1979) Yield response to water. FAO Irrigation and Drainage, Paper 33, Rome, 193 p.

[23] Prueger, J.H., Hatfield, J.L. and Aase, J.K. (1997) Bowen-ratio comparisons with lysimeter evapotranspiration. Agronomy Journal, 89, 730-736. doi:10.2134/agronj1997.00021962008900050004x

[24] Azevedo, P.V., Silva, B.B. and Silva, V.P.R. (2003) Water requirements of irrigated mango orchards in northeast Brazil. Agriculture Water Management, 58, 241-254. doi:10.1016/S0378-3774(02)00083-5

[25] Silva, V.P.R., Azevedo, P.V. and Silva, B.B. (2007) Surface energy fluxes and evapotranspiration of a mango orchard grown in a semiarid environment, Agronomy Journal, 99, 1391-1396. doi:10.2134/agronj2006.0232

[26] Perez, P.J., Castellvi, F., Ibanez, M. and Rosell, J.I. (1999) Assessment of reliability of Bowen ratio method for partitioning fluxes. Agriculture and Forest Meteorology, 97, 141-150. doi:10.1016/S0168-1923(99)00080-5

[27] Thind, H.S., Aujla, M.S. and Buttar, G.S. (2008) Response of cotton to various levels of nitrogen and water applied to normal and paired sown cotton under drip irrigation in relation to check-basin. Agriculture Water Management, 95, 25-34. doi:10.1016/j.agwat.2007.08.008

[28] Silva, F.A.S. (1996) The ASSISTAT Software: Statistical assistance. International Conference on Computers in Agriculture, Transactions on the American Society of Agriculture Engineering, 1, 294-298.

[29] Rosenberg, N.J., Blad, B.L. and Verna, S.B. (1983) Microclimate: The biological environment. John Wiley and Sons, New York, $495 \mathrm{p}$.

[30] Karam, F., Lahoud, R., Masaad, R., Daccache, A., Mounzer, O. and Rouphael, Y. (2006) Water use and lint yield response of drip irrigated cotton to the length of irrigation season. Agriculture Water Management, 85, 287 295. doi:10.1016/j.agwat.2006.05.003

[31] Ko, J., Piccinni, G., Marek, T. and Howell, T. (2009) Determination of growth-stage-specific crop coefficients $\left(\mathrm{K}_{\mathrm{c}}\right)$ of cotton and wheat. Agriculture Water Management, 96, 1691-1697. doi:10.1016/j.agwat.2009.06.023

[32] Martin, S.W. and Hanks, J. (2009) Economic analysis of no tillage and minimum tillage cotton-corn rotations in the Mississippi Delta. Soil Tillage Research, 102, 135137. doi:10.1016/j.still.2008.08.009

[33] Wright, G.C., Nagaswara-Rao, R.C. and Farquhar, G.D. (1994) Peanut cultivar variation in water-use efficiency and carbon isotope discrimination under drought conditions in the field. Crop Science, 34, 92-97. doi:10.2135/cropsci1994.0011183X003400010016x

[34] Du, T., Kang, S., Zhang, J., Li, F. and Hu, X. (2006) Yield and physiological responses of cotton to partial root-zone irrigation in the oasis field of northwest China. Agriculture Water Management, 84, 41-52. doi:10.1016/j.agwat.2006.01.010 